\title{
Casual Nexus Between Dynamics of Population and Food Security: Economic Benchmarks for Agriculture
}

\author{
Natalia Vasylieva ${ }^{1}$ \\ ${ }^{1}$ Dnipro State Agrarian and Economic University, Ukraine \\ Correspondence: Natalia Vasylieva, Dnipro State Agrarian and Economic University, Serhiya Yefremova Str., 25, \\ Dnipro 49600, Ukraine. Tel: 380-9-8033-4900. E-mail: VasylievaN@i.ua
}

Received: June 23, 2020

Accepted: July 30, 2020

Online Published: August 14, 2020

doi:10.5430/rwe.v11n4p33

URL: https://doi.org/10.5430/rwe.v11n4p33

\begin{abstract}
Food security and dynamics of population have a dual connection. Firstly, a rapid rise in the population size increases a demand for food. Secondly, a lack of food affordability and availability implies negative dynamics of population. The latter issue observed in Ukraine highlighted the goal of this research. The methodological study background was econometrics and cluster comparative analysis. The considered time series covered the period 1999 to 2018 . The accessible cross-sectional data included 90 countries. The research outcome in the form of multiple regressions allowed forecasting the objective values of expenditures on food, income per capita, and daily protein intakes which could retain a stable population size. The offered EU and World Top benchmarks involved the GDP indicator, balance between crop and animal food supplies, medium age, and share of rural population by country. These findings made possible to set prospects of amplifying Ukrainian food security and improving population dynamics.
\end{abstract}

Keywords: dynamics of population, food affordability, food availability, EU and World Top groups, agricultural benchmarks

\section{JEL Classification: O13, Q56}

\section{Introduction}

Providing affordable and available food products is a primary socioeconomic mission of every state. Meanwhile, its accomplishment became more complicated. Firstly, a rapid population growth enhanced a global issue of combating hunger in the developing countries. Secondly, the developed countries encountered with irrational food baskets which affect people's health. Thirdly, broken food security in the post-communist countries resulted in negative dynamics of population caused by sharp disproportions between rates of births, deaths and migrants' flows.

Hence, maintenance of the balanced nutrition intake appeared to be a new challenge, in general, for the world agriculture and, in particular, for Ukrainian one. For such reasons, problems in question belong to the top-agenda of the international scientific community. That is why the presented research was focused on demographic and agricultural aspects, i.e. reflections of food demand and supply, concerning prospects of Ukraine in the global and European scales.

The paper is organized as follows. The next section provides a summary over demography and food security issues in the relevant literature. Sections 3 and 4 incorporate information on the applied methods and empirical findings. Section 5 discusses the research outcomes. Section 6 concludes the study.

\section{Literature Review}

Numerous recent scientific studies addressed issues of food security. One of them was a complex research conducted by Gardner (2013) who focused on macroeconomic, technological, financial, environmental, dietary, and trade topics of providing sufficient agricultural production and food supply for over 9 billion people by 2050. Meyers and Kalaitzandonakes (2015) assessed the challenges of the ongoing climate change and forthcoming resource constraints which would have the agricultural impact of the world-wide scope, especially over grain and oilseed supplies for food, feed, and bio-fuel. Grafton et al. (2015) evaluated necessary farm inputs and investments to meet an increased demand for food in the view of the rises in the population size, urbanization, incomes per capita as well as requirements on products' quality. McKenzie and Williams (2015) examined options and gave the ways to foster food security via integrated ecological intensification, sustainable governance and balanced management that can 
provide affordable and available food before and beyond 2050. Alfieri (2016) set links between political, economic, and demographic components of food sustainability and security navigating limitations of the cultivated croplands, encouragements for mixed ecological and genetically modified farming, support to smallholders, reductions in post-harvest losses, promotions of elastic fair trade and rational nutritional dietary. In other words, agricultural activity must be a profitable business which is strongly committed to fulfilling its social and ecological duties (Velychko and Velychko, 2017).

Lately, many scientists explored and created advanced applications of mathematical methods to forecasting food security. Actually, Valin et al. (2014) reviewed model approaches under various scenarios of socioeconomic development, price elasticity, climate change, and bio-energy expansion that resulted in different expected proportions between the consumed calories obtained from animal and crop origins. Meanwhile, Stavytskyy and Prokopenko (2014) built a panel regression model to summarize regional trends in providing food security. They considered indicators of daily intake of calories, crop yields, gross added value per capita, indices of consumer prices, employment, direct foreign investments as well as integral assessments of ecology, health, and medicine states with regard to Ukrainian statistical samples. Edmonds et al. (2017) shaped models of food demands for staple and non staple products driven by incomes per capita. Flies et al. (2018) investigated uniform assessments of accuracy and uncertainty in predicting future food demands through time-series and income-based models. Besides, Vasylieva (2015) submitted a complex of econometric production model and optimization consumption model to foster food security in animal sector and exhibit scenarios of the probable shifts in export-import operations.

Despite the existing mathematical results, there is still an open question concerning food security influence over demographic dynamics and consequences of these socioeconomic challenges for agricultural development. To address this object this study incorporated three tasks about:

- creating econometric models intended to describe dynamics of Ukrainian population associated with indicators of food affordability and availability;

- specifying European projection over demographic dynamics and food security to set some short-run prospects for the relevant development in Ukraine;

- obtaining the world projection over demographic dynamics and food security to evaluate the long-run benchmarks for Ukrainian agriculture.

\section{Methodology}

A methodological background to the first research task was econometrics (Studenmund, 2016). Following recommendations of the Food and Agriculture Organization of the United Nations, the conducted study was built on the accessible indicators of food affordability and availability (Vasylieva, 2019). The selected ones were

$X_{1}-$ a share of expenditures on food per capita, in \%;

$X_{2}-$ an average monthly income per capita, in \$;

$X_{3}$ - a daily intake of protein obtained from the crop origins, in g per capita;

$X_{4}$ - a daily consumption of protein derived from the animal origins, in $\mathrm{g}$ per capita.

A mathematical framework describing an annual change in the population size $(Y)$ reduced to two linear multiple regressions highlighting the impacts of food security components like

$$
\begin{aligned}
& Y=A_{1} \cdot X_{1}+A_{2} \cdot X_{2}, \\
& Y=A_{3} \cdot X_{3}+A_{4} \cdot X_{4}
\end{aligned}
$$

with the numerical coefficients $A_{1}-A_{4}$.

It should be noted that both of $Y$ intercept-coefficients in the formulas (1) and (2) were omitted since possible values of the independent variables $X_{1}-X_{4}$ are always greater than 0 .

A theoretical background to the second and third research tasks was the method of comparative group analysis by average indices (Mitchell, 2011). To explore target countries, there were selected 5 basic and 3 additional indicators including

$$
\begin{aligned}
& Z_{1} \text { - an annual change in the population size, in } \% ; \\
& Z_{2} \text { - a share of expenditures on food per capita, in } \% ; \\
& Z_{3} \text { - a total daily protein supply, in g per capita; }
\end{aligned}
$$


$Z_{4}-$ a daily supply of protein derived from the animal origins, in g per capita;

$Z_{5}$ - a yearly agricultural production per capita, in Int\$;

$Z_{6}-$ GDP per capita, in Int\$;

$Z_{7}-$ a share of rural population, in $\%$;

$Z_{8}-$ a medium people's age, in years.

To justify the choice of these indicators it is worth mentioning that, firstly, $Z_{2}$ and $Z_{6}$ characterized purchasing power of domestic consumers and stated ability to underpin food security. Secondly, $Z_{3}-Z_{5}$ described a balance between agricultural industries and a total effectiveness of the national farming. Thirdly, $Z_{7}$ and $Z_{8}$ showed reserves of involving population in the agricultural activity as well as expected trends in nutrition and diet depending on people's age and location area.

A mathematical framework for exhibiting benchmarks to providing food security consisted of the relative indices $\Delta Z_{i}, \quad i=1, . .5$, like

$$
\begin{gathered}
\Delta Z_{1}=Z_{1}-Z_{1}^{*}, \\
\Delta Z_{i}=\left(Z_{i}-Z_{i}^{*}\right) / Z_{i}^{*}, \quad i=2, . .5,
\end{gathered}
$$

where $Z_{i}^{*}$ were the reference points to the indicators $Z_{i}, i=1, . .5$.

In particular, formulas (3), (4) for the second research task concerned the EU member states compared with Ukrainian indicators. Similarly, formulas (3), (4) associated with the third research task corresponded to the World Top countries with regard to Ukrainian figures.

\section{Research Results}

The initial data to the first research task consisted of time-series for 1999-2018 (State statistics service of Ukraine, 2019). Being a statistical spike, the observation for 2014 was excluded from calculations since then there was a sharp drop in size of Ukrainian population caused by the annexation of the Crimea and partial occupation of Donbass.

The computed parameters of regressions (1) and (2) revealed the impacts of food affordability and availability over the annual dynamics of Ukrainian population (see Table 1).

\begin{tabular}{|c|c|c|c|c|}
\hline \multirow{2}{*}{ Parameters } & \multicolumn{2}{|c|}{ Regression (1) } & \multicolumn{2}{|c|}{ Regression (2) } \\
\hline & $X_{1}$ & $X_{2}$ & $X_{3}$ & $X_{4}$ \\
\hline Coefficient $\left(A_{i}\right)$ & -0.012 & 0.001 & -0.032 & 0.024 \\
\hline $\mathrm{P}$-value & 0.000 & 0.028 & 0.000 & 0.000 \\
\hline R-squared & \multicolumn{2}{|c|}{0.965} & \multicolumn{2}{|c|}{0.976} \\
\hline F-significance & \multicolumn{2}{|c|}{0.000} & \multicolumn{2}{|c|}{0.000} \\
\hline
\end{tabular}

Table 1. Output for regressions about food security influence over Ukrainian demography

Source: calculated by the author.

Ukrainian integration in Europe implies that the primary data to the second research task can be the current values of the indicators $Z_{1}-Z_{8}$ in the EU countries. The accessible cross-sectional data covered $25 \mathrm{EU}$ countries except for Cyprus, Luxemburg, and Malta (FAO, 2019; USDA, 2019; Worldometers, 2019). The sample observations were distributed into 3 groups by the change in the population size compared to Ukrainian one. Namely, 1 EU group contained Bulgaria, Croatia, Latvia, Lithuania, and Romania with essential falls in their population sizes (negative and worse than in Ukraine); 2 EU group included Greece, Hungary, Italy, Poland, and Portugal with slight drops in 
their population sizes (negative but better than in Ukraine); 3 EU group aggregated Austria, Belgium, the Czech Republic, Denmark, Estonia, Finland, France, Germany, Ireland, the Netherlands, Slovakia, Slovenia, Spain, Sweden, and the United Kingdom with gradual increments in their population sizes.

The corresponding average values of the indicators $Z_{1}-Z_{8}$ were collected in Table 2 .

Table 2. Input data on the EU benchmarks for Ukrainian food security

\begin{tabular}{lcccccccc}
\hline Countries & $Z_{1}$ & $Z_{2}$ & $Z_{3}$ & $Z_{4}$ & $Z_{5}$ & $Z_{6}$ & $Z_{7}$ & $Z_{8}$ \\
\hline Ukraine & -0.59 & 40 & 84 & 42 & 398 & 9233 & 31 & 41 \\
\hline 1 EU group & -0.89 & 23 & 93 & 51 & 333 & 28702 & 34 & 44 \\
\hline 2 EU group & -0.26 & 17 & 102 & 56 & 338 & 33455 & 30 & 45 \\
\hline 3 EU group & 0.33 & 13 & 101 & 61 & 341 & 49019 & 24 & 42
\end{tabular}

Source: composed by the author.

The EU benchmarks on improving demographic and agricultural development in Ukraine were depicted in Figure 1.

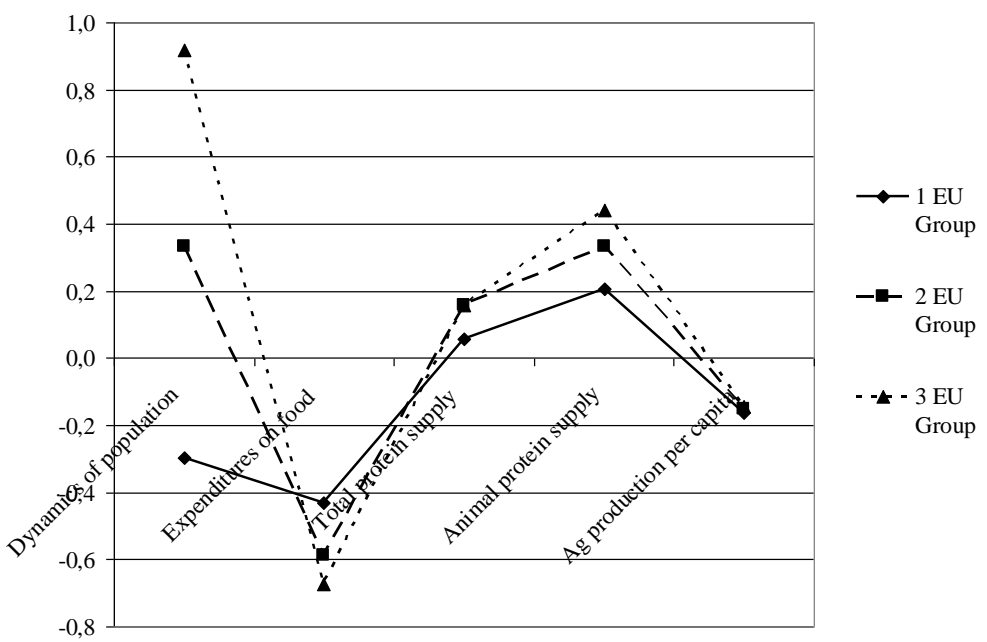

Figure 1. The EU benchmarks for Ukrainian food security

Source: elaborated by the author.

Cross-sectional data to the third research task incorporated the World Top 5 countries according to 5 basic indicators $Z_{1}-Z_{5}$ which address demographic and agricultural aspects of food security. The accessible number of sample observations was 90 (FAO, 2019; USDA, 2019; Worldometers, 2019). Namely, 1 World Top group included Cameroon, Guatemala, Kenya, Nigeria, and Pakistan which had the highest annual population growth; 2 World Top group consisted of Canada, Ireland, Switzerland, the United Kingdom, and the USA which had the lowest shares of expenditures on food; 3 World Top group contained France, Italy, the Netherlands, Norway and Portugal with the largest total daily protein supply; 4 World Top group aggregated Australia, Finland, Israel, the Netherlands, and Sweden with the largest daily supply of protein derived from the animal origins; 5 World Top group assembled Argentina, Australia, Denmark, New Zealand, and Uruguay which had the largest agricultural production per capita. The average values of the indicators $Z_{1}-Z_{8}$ within the listed groups were congregated in Table 3 . 
Table 3. Input data on the World benchmarks for Ukrainian food security

\begin{tabular}{lcccccccc}
\hline Countries & $Z_{1}$ & $Z_{2}$ & $Z_{3}$ & $Z_{4}$ & $Z_{5}$ & $Z_{6}$ & $Z_{7}$ & $Z_{8}$ \\
\hline Ukraine & -0.59 & 40 & 84 & 42 & 398 & 9233 & 31 & 41 \\
\hline 1 World Top group & 2.28 & 48 & 64 & 16 & 145 & 5454 & 55 & 21 \\
\hline 2 World Top group & 0.78 & 8 & 103 & 61 & 400 & 61632 & 23 & 40 \\
\hline 3 World Top group & 0.16 & 14 & 110 & 67 & 343 & 48485 & 22 & 44 \\
\hline 4 World Top group & 0.76 & 13 & 107 & 72 & 369 & 49907 & 11 & 39 \\
\hline 5 World Top group & 0.73 & 16 & 99 & 62 & 885 & 38504 & 10 & 37 \\
\hline
\end{tabular}

Source: composed by the author.

Examination of the group 1 substantiated Ukrainian possibilities in supporting the global food supply. Analysis of the groups 2-5 enabled to set benchmarks for improvements of Ukrainian food security. A chart to the conducted comparisons was visualized in Figure 2.

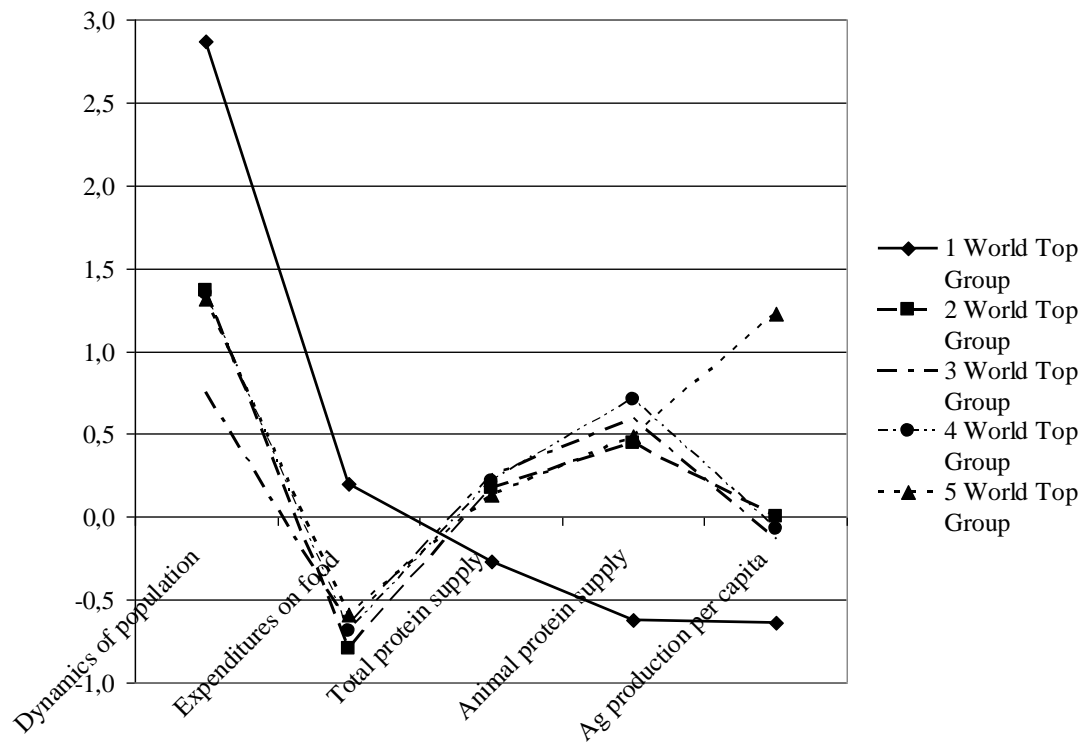

Figure 2. The world benchmarks for Ukrainian food security

Source: elaborated by the author.

\section{Discussion}

As distinct from the fundamental mathematical demographic models created by Preston et al. (2000), Keyfitz and Caswell (2010), results of this study were focused on proving impacts of food affordability and availability over dynamics of population which took place in Ukraine as one of the post-communist countries with a negative change in the population size. The performed calculations confirmed a high level of significance (over 95\%) for the obtained regressions (see Table 1).

More specifically, the found coefficient $A_{1}$ in formula (1) means that an additional $1 \%$ to the share of expenditures on food per capita in Ukraine would cause a fall in the population size by $0.012 \%$. On the contrary, the computed coefficient $A_{2}$ in formula (1) assumes that additional \$10 to the average monthly income per capita in Ukraine 
would enlarge the population size by $0.01 \%$. Eventually, formula (1) made it possible to forecast that after rising $X_{2}$ up to $\$ 296.4$ and decreasing $X_{1}$ down to $19.1 \%$ (i.e. retaining the absolute sum of monthly expenditures on food per capita around \$56.5) the size of Ukrainian population could become stable ( $Y=0 \%)$. The desired inputs seem rather appropriate because the minimal monthly wage in the EU is over $\$ 300$ and the average share of expenditures on food accounts for 15.7\% (USDA, 2019). However, an economic base of such steps assumes a separate thorough research given Ukrainian issues and prospects of managerial and innovative updating (Malyarets et al., 2019; Babenko, 2019), economic growth (Katan et al., 2018), and financial restrictions (Khalatur et al., 2018).

The found coefficient $A_{3}$ in formula (2) appeared to be negative. It could be explained in such way. People have to switch to consuming cheaper crop proteins through difficult times, and vice versa. Meanwhile, poor purchasing power of Ukrainian population limits a total increase in the protein intake. So, the calculated coefficient $A_{3}$ in formula (2) admits that an additional $1 \%$ of the consumed crop protein would correspond to a fall in the population size by $0.032 \%$. On the contrary, the computed coefficient $A_{4}$ in formula (2) implies that an additional $1 \%$ of the consumed animal protein would detect a growth in the population size by $0.024 \%$.

It is a scientific fact that a protein deficiency causes various serious health complications (Khan et al., 2017; Babenko et al., 2019). Formula (2) is applicable to prevent them and stabilize the size of population in Ukraine. Indeed, in case of keeping the current value of $X_{3}=42.1 \mathrm{~g}$ and increasing $X_{4}$ up to $55.6 \mathrm{~g}$ the size of Ukrainian population could retain stable $(Y=0 \%)$. The desired inputs seem rather accessible since the average daily consumption of protein obtained from the animal origins equals to $58 \mathrm{~g}$ per capita in the EU (FAO, 2019). An extra $31.7 \%$ of animal products set an exact benchmark for improving effectiveness of Ukrainian animal husbandry which remains in a prolonged crisis (Vasylieva et al., 2015).

Table 2 identified tendencies in dynamics of population and food security indicators related to the EU. The world crisis of 2008 brought there some ongoing consequences (Davis and Geiger, 2017). Actually, the Group 1 combined 5 countries with negative changes in the population sizes which were even more critical than in other countries, non-members of the EU, such as Belarus, Bosnia-Herzegovina, Georgia, Japan, Serbia, and Venezuela. The indicators $Z_{1}$ were better in 5 countries of the Group 2 and quiet optimistic in 15 counties of the Group 3. Overall, the growth in the population size was accompanied by the upward trends in nutritional qualities of food baskets (owing to the indicators $Z_{3}$ and $Z_{4}$ ) and people's welfare (according to the indicators $Z_{2}$ and $Z_{6}$ ), a gradual urbanization process and shrinking population in countries with older domestic consumers (see, respectively, the indicators $Z_{7}$ and $Z_{8}$ ). Lower quantities of agricultural production per capita (the indicator $Z_{5}$ ) determined new opportunities for Ukrainian agrarian export at the EU vector.

The chart in Figure 1 defined clear benchmarks to Ukrainian agriculture. Specifically, animal husbandry must be ready for providing additional $33 \%$ and, further, $44 \%$ of its products. However, these demands would appear after a double reduction in the share of expenditures on food. A promising signal to Ukraine is an advantage over the EU countries in agricultural production per capita at least by $14 \%$. Nevertheless, under the contemporary complicated economic realities Ukrainian agriculture became a donor of the state budget and cannot benefit from investing the obtained profits in its own innovative development. The downward trend in the share of rural population highlighted that Ukrainian agriculture would need more machinery and technical means for effective agricultural operation. Almost the same average age of population inferred, on the one hand, the similar nourishing needs, and, on the other hand, coinciding experiences and potentials of the labor force.

Table 3 and Figure 2 dealt with the world tendencies in dynamics of population and food security indicators. Really, the Top Group 1 gathered countries with the quickest population growth (annually by $2.28 \%$ ). Unfortunately, it is not supported by the national agricultural achievements though the share of the country folk amounted to $46 \%$ (Van Bavel, 2013; Kavallari et al., 2014; Mikalauskiene et al., 2018). Moreover, the share of expenditures on food, total and animal protein supplies, agricultural production as well as GDP per capita within the Top Group 1 were worse by 8 percentage point, $27 \%, 62 \%, 64 \%$ and $41 \%$ than those ones in Ukraine. The average age of population in the countries of the Top Group 1 was only 21 that mirrored the urgent international appeal "Help to Feed the Future". It 
gives essential incentives to Ukrainian participation in underpinning global food security that can be amplified in the grain and oilseed export segments (Vasylieva, 2018).

The Top Group 2 united countries which set the world benchmarks to the optimal food security system accompanied by the annual population growth by $0.78 \%$. Their pattern justifies that Ukraine should try to reduce the share of expenditures on food as well as increase total and animal protein supplies by 32 percentage point, $18 \%$ and $45 \%$. At the same time, the agricultural production per capita within the Top Group 2 nearly coincided with Ukrainian indicator that is a significant positive message to the agricultural development in Ukraine.

The Top Group 3 was created by the countries with the highest total protein supply which surpassed Ukrainian indicator by $25 \%$ and arranged a long-run objective for providing food security in the context of an aging population.

The Top Group 4 incorporated the wealthiest countries with the largest animal protein intake which was twice as much as the protein supply from crop products. Thus, Ukrainian animal husbandry might implement the most effective world practices applied by the farmers of the given group.

Finally, the Top Group 5 consolidated countries which had the agricultural production per capita about 2.2 times more than the Ukrainian indicator. Besides, their average GDP per capita was 4.2 times more than in Ukraine. Meanwhile the share of rural population in the Top Group 5 was less by 21 percentage point with regard to Ukrainian one. Hence, the long-run benchmark for establishing effective agriculture in Ukraine should be concentrated on a sufficient financial maintenance, comprehensive mechanization, maximum automation, and also wide engagement of highly productive workers.

\section{Conclusions}

The completed research can be summarized by the following recommendations and proposals dedicated to demographic and agricultural aspects of providing food security.

Ukraine is among 17 countries which had negative annual changes in the population sizes. To a large extent, such tendency was caused by the insufficient food affordability and availability. The developed multiple regressions allowed to forecast that increases in an average income per capita and a daily consumption of animal proteins, respectively, from $\$ 141.1$ to $\$ 296.4$ and from $42.2 \mathrm{~g}$ to $55.6 \mathrm{~g}$ would stabilize the size of Ukrainian population.

Since Ukraine is focused on the EU integration, it is relevant to clarify the key EU benchmarks on agricultural development and population dynamics. The performed comparative analysis proved that a decrease in the share of expenditures on food by 23 percentage point and an increment of the total protein supply by $16 \%$ should be the nearest objectives of enhancing Ukrainian food security. On the plus side, the national agricultural production per capita exceeds the one in the EU on average by $15 \%$ that reveals optimistic export prospects of Ukrainian agriculture to the EU member states.

The comparative analysis of the World Top countries generated primary long-term benchmarks over agricultural and demographic components of Ukrainian food security. The group of countries with the largest annual changes in their population sizes by $2.28 \%$ had high spending on food, poor protein consumption, and low agricultural production per capita, which were explained by prevalent young population of 21 years old. Therefore, Ukrainian agriculture ought to meet this socioeconomic international challenge and expand its contribution to the global food supply. Overall, the group of countries with the minimum share of expenditures on food gave the pattern of robust food security which maintained the justified annual rise in the population size by $0.78 \%$. The group of countries with the maximal animal protein supply grounded the reliable benchmark for Ukrainian animal husbandry concerning an increase in production by $70 \%$ that needs only $11 \%$ of rural population. At last, the group of countries with the highest agricultural production per capita of Int $\$ 885$ introduced the credible benchmark to double effectiveness of Ukrainian agriculture with well-balanced crop and animal farming.

\section{References}

Alfieri, F. (2016). Politics, economics, and demographics of food sustainability and security. Reference Module in Food Science of Elsevier Inc. https://doi.org/10.1016/B978-0-08-100596-5.03435-1

Babenko, V. (2019). Formalization of the Model of Management of the Technological Innovations. CEUR Workshop Proceedings, 2393, 595-602. Retrieved from http://ceur-ws.org/Vol-2393/paper_431.pdf

Babenko, V., Gaponova, E., Nehrey, M., Ryzhikova, N., \& Zaporozhets, E. (2019). Life Expectancy of Population of the Country: the Role of Health Services Effectiveness. Research in World Economy, 10(4), 86-91. https://doi.org/10.5430/rwe.v10n4p86 
Davis, O., \& Geiger, B. B. (2017). Did food insecurity rise across Europe after the 2008 Crisis? An analysis across welfare regimes. Social Policy and Society, 16(3), 343-360. https://doi.org/10.1017/S1474746416000166

Edmonds, J. A., Link, R., Waldhoff, S. T., \& Cui, R. (2017). A global food demand model for the assessment of complex Human-Earth systems. Climate Change Economics, 8(4), 1750012. https://doi.org/10.1142/S2010007817500129

FAO. (2019). Food security, Economic and social development department, UN Statistics. Retrieved from http://www.fao.org/economic/ess/ess-fs/en/

Flies, E. J., Brook, B. W., Blomqvist, L., \& Buettel, J. C. (2018). Forecasting future global food demand: A systematic review and meta-analysis of model complexity. Environment International, 120, 93-103. https://doi.org/10.1016/ j.envint.2018.07.019

Gardner, B. (2013). Global Food Futures: Feeding the World in 2050. London, England: Bloomsbury Academic.

Grafton, R. Q., Daugbjerg, C., \& Qureshi, M. E. (2015). Towards food security by 2050. Food Security, 7(2), 179-183. https://doi.org/10.1007/s12571-015-0445-x

Katan, L., Dobrovolska, O., \& Espejo, J. M. R. (2018). Economic growth and environmental health: a dual interaction. Problems and Perspectives in Management, 16(3), 219-228. https://doi.org/10.21511/ppm.16(3).2018.18

Kavallari, A., Fellmann, T., \& Gay, S. H. (2014). Shocks in economic growth = shocking effects for food security?. Food Security, 6(4), 567-583. https://doi.org/10.1007/s12571-014-0368-y

Keyfitz, N., \& Caswell, H. (2010). Applied Mathematical Demography. New York, NY: Springer.

Khalatur, S., Pavlova, G., \& Zhylenko, K. (2018). The role of some indicators of financial security in Ukraine in the context of transnationalization and national interests. Investment Management and Financial Innovations, 15(3), 237-248. https://doi.org/10.21511/imfi. 15(3).2018.20

Khan, A., Khan, S., Jan, A. A., \& Khan, M. (2017). Health complication caused by protein deficiency. Journal of Food Science and Nutrition, 1(1), 1-2. Retrieved from http://www.alliedacademies.org/articles/health-complication-caused-by-protein-deficiency-8550.html

Malyarets, L. M., Babenko, V. O., Nazarenko, O. V., \& Ryzhikova, N. I. (2019). The Modeling of Multi-criteria Assessment Activity in Enterprise Management. International Journal of Supply Chain Management, 8(4), 997-1004. Retrieved from https://ojs.excelingtech.co.uk/index.php/IJSCM/article/view/3342/1857

McKenzie, F. C., \& Williams, J. (2015). Sustainable food production: constraints, challenges and choices by 2050. Food Security, 7(2), 221-233. https://doi.org/10.1007/s12571-015-0441-1

Meyers, W. H., \& Kalaitzandonakes, N. (2015). World Population, Food Growth, and Food Security Challenges. In Schmitz, A., Kennedy, P. L., \& Schmitz, T. G. (Eds.), Food Security in an Uncertain World (Frontiers of Economics and Globalization, Vol. 15, pp. 161-177). Bingley, England: Emerald Group Publishing Limited.

Mikalauskiene, A., Narutaviciute-Cikanauske, R., Sarkiunaite, I., Streimikiene, D., \& Zlateva, R. (2018). Social Aspect of Sustainable Development: Issues of Poverty and Food Shortage. Montenegrin Journal of Economics, 14(2), 59-78. https://doi.org/10.14254/1800-5845/2018.14-2.4

Mitchell, N. H. (2011). Mathematical Applications in Agriculture. Boston, MA: Cengage Learning.

Preston, S. H., Heuveline, P., \& Guillot, M. (2000). Demography: Measuring and Modeling Population Processes. Oxford, England: Wiley-Blackwell Publishers.

State statistics service of Ukraine. (2019). Agriculture in Ukraine, Statistics. Retrieved from http://www.ukrstat.gov.ua

Stavytskyy, A. V., \& Prokopenko, O. O. (2014). Modelling the food security in Ukraine. Ekonomika, 93(3), 102-115. Retrieved from http://www.journals.vu.lt/ekonomika/article/ view/3881/2693

Studenmund, A. H. (2016). Using Econometrics: A Practical Guide. London, England: Pearson plc.

USDA. (2019). Food Expenditure Series, Economic Research Service of the US Department of Agriculture, Statistics. Retrieved from https://www.ers.usda.gov/

Valin, H., Sands, R. D., van der Mensbrugghe, D., Nelson, G. C., Ahammad, H., Blank, E., \& Willenbockel, D. (2014). The future of food demand: understanding differences in global economic models. Agricultural Economics, 45(1), 51-67. https://doi.org/10.1111/agec.12089 
Van Bavel, J. (2013). The world population explosion: causes, backgrounds and projections for the future. Facts, views \& vision in ObGyn, 5(4), 281-291. Retrieved from https://www.ncbi.nlm.nih.gov/pmc/articles/PMC3987379/

Vasylieva, N. (2015). Economic and mathematical models of regional meat and milk cluster development. Actual Problems of Economics, 165(3), 429-435. Retrieved from https://eco-science.net/downloads/

Vasylieva, N. (2018). Ukrainian Agricultural Contribution to the World Food Security: Economic Problems and $\begin{array}{lllll}\text { Prospects. Montenegrin Journal of } & \text { 215-224. }\end{array}$ https://doi.org/10.14254/1800-5845/2018.14-4.15

Vasylieva, N. (2019). Problems and Prospects of Food Security in Ukraine. Bulgarian Journal of Agricultural Science, 25(4), 668-676. Retrieved from https://www.agrojournal.org/25/04-08.pdf

Vasylieva, N., Vinichenko, I., \& Katan, L. (2015). Economic and mathematical evaluation of Ukrainian agrarian market by branches. Economic Annals-XXI, 154(9-10), 41-44. Retrieved from http://soskin.info/userfiles/file/2015/9-10_2015/Vasylieva_Vinichenko_Katan.pdf

Velychko, O., \& Velychko, L. (2017). Logistical modelling of managerial decisions in social and marketing business systems. Journal of International Studies, 10(3), 206-219. https://doi.org/10.14254/2071-8330.2017/10-3/15

Worldometers (2019). Countries in the world by population, Real Time Statistics Project. Retrieved from http://www.worldometers.info/

\section{Copyrights}

Copyright for this article is retained by the author(s), with first publication rights granted to the journal.

This is an open-access article distributed under the terms and conditions of the Creative Commons Attribution license (http://creativecommons.org/licenses/by/4.0/). 